\title{
Factors affecting haemolysin production and Congo red binding in Salmonella enterica serovar Typhimurium DT 98
}

\author{
R. P. TIWARI, KAMALDEEP DEOL, PARVEEN RISHI and J. S. GREWAL* \\ Department of Microbiology, Panjab University, Chandigarh-160014 and *Malaria Group, International Centre \\ for Genetic Engineering \& Biotechnology, PO Box 10504, Aruna Asaf Ali Marg, New Delhi-110067, India
}

\begin{abstract}
Differences in haemolysin expression were observed in a strain of Salmonella enterica serovar Typhimurium definitive phage type (DT) 98 cultured under various conditions. Haemolysin expression was optimal in cultures grown micro-aerobically. The zones of haemolysis were wider after longer periods of incubation. Haemolysin production varied after growth in the following media (greatest to least): brain heart infusion (BHI) broth $>$ nutrient broth $(\mathrm{NB})>$ trypticase soy broth $($ TSB) $>$ M-9 glucose medium. Haemolysin production correlated directly with Congo red binding in nutrient broth. On Congo red blood agar, colonies were smaller, with dark centres and wider zones of haemolysis. Culture-cell-free haemolysin activity was higher, but cell-bound haemolysin activity was very low in growth medium supplemented with Congo red. Boiled tea extract at $25 \% \mathrm{v} / \mathrm{v}$ (of $25 \% \mathrm{w} / \mathrm{v}$ tea infusion) in PBS and nutrient broth was bactericidal to $S$. Typhimurium DT 98. The addition of boiled tea extract to growth medium inhibited haemolysin production by $S$. Typhimurium DT 98 at higher concentrations (6$12.5 \% \mathrm{v} / \mathrm{v})$ but stimulated haemolysin production at lower concentrations $(1.5-3 \% \mathrm{v} / \mathrm{v})$. The pre-treatment of bacterial cell suspensions with lower concentrations of tea extract $(1.5-3 \% \mathrm{v} / \mathrm{v})$ also altered the Congo red binding, which showed an inverse correlation in nutrient broth.
\end{abstract}

\section{Introduction}

Salmonellosis is a multistage, multifactorial, hostdependent and often host-restricted infection [1]. Despite intensive studies, the number, nature and role of salmonella toxins in disease production remain unclear. The pathogen enters the gastrointestinal tract in contaminated food and water, attaches to and penetrates the small intestinal epithelium and then spreads to other internal organs $[2,3]$.

Exposure of Salmonella enterica serovar Typhimurium to moderate stress results in the synthesis of several proteins [4], including haemolysin, previously called cytolysin $[5,6]$. At least six regulatory classes of nutrient, starvation-inducible loci have been characterised for the salmonellae [7]. To assign biological significance to any putative character or virulence

Received 7 March 2000; revised version received 4 June 2001; accepted 3 Dec. 2001.

Corresponding author: Dr R. P. Tiwari (e-mail: ramptiwari @yahoo.com; jasvirgrewal@usa.net). determinant, it is necessary to demonstrate its expression and sometimes its extracellular release in relation to host environmental cues or in appropriate ecological settings.

The present study investigated the expression of one such putative factor, haemolysin, together with the ability of $S$. Typhimurium definitive phage type (DT) 98 to bind Congo red. Cultural conditions are known to affect the induction of virulence traits $[8,9]$. Enteropathogenicity has been correlated with the initial invasion of the intestinal epithelium that is necessary for infection to become established, and with increased haemolysin production [10-12]. The regulatory effect of Congo red on membrane protein is mediated through induction, and experiments with Shigella flexneri phage type 2a have suggested that Congo red mimics host tissue factor in vitro [13]. The Congo red binding technique has been used to determine the cell surface protein array involved in the virulence of Aeromonas salmonicida [14]. The appropriate regulation of genes enables $S$. Typhimurium to adapt to the intracellular environment of the host [15]. The initial penetration 
and destruction of M cells by invasive $S$. Typhimurium, followed by secondary invasion of adjacent enterocytes, has been attributed to the balanced production of haemolysin by $S$. Typhimurium [16, 17].

Tea extracts have been shown to have antibacterial properties [18-20]. Toda et al. [18] have reported that black or green tea inhibits the growth of a number of enteric bacteria. This prompted the investigation of the effects of tea extract on the viability and haemolysin production of $S$. Typhimurium DT 98 .

\section{Materials and methods}

\section{Bacterial strains}

$S$. Typhimurium DT 98 was selected for this study from 18 strains of $S$. Typhimurium and 11 of $S$. Typhi because it showed the greatest haemolytic activity [21]. The strain was maintained on Le Minor medium agar slopes [22] in screw-capped tubes at $4^{\circ} \mathrm{C}$, and subcultured bimonthly.

\section{Screening for haemolysin activity}

Each test strain was cultured under micro-aerobic conditions on overlayered blood agar at $37^{\circ} \mathrm{C}$ [21]. The strain was spread on blood agar plates, which were incubated at $37^{\circ} \mathrm{C}$ for $4 \mathrm{~h}$, overlayered with an additional layer of nutrient agar, and incubated at $37^{\circ} \mathrm{C}$ for a further $72 \mathrm{~h}$, during which they were examined daily for haemolysis.

\section{Preparation of cell-free supernate and bacterial cell suspension}

$S$. Typhimurium DT 98 was cultured for $16 \mathrm{~h}$ at $37^{\circ} \mathrm{C}$ in nutrient broth $(30 \mathrm{ml} / 100 \mathrm{ml}$ flask), which was then centrifuged at $7000 \mathrm{~g}$ for $15 \mathrm{~min}$ at $4^{\circ} \mathrm{C}$. The clear, culture-cell-free supernate (CCFS) was separated carefully with a sterile pasteur pipette, taking care not to disturb the bacterial pellet. The supernate was filtersterilised through a membrane filter (Millipore; 0.45 $\mu \mathrm{m})$ and stored in a sterile vial for subsequent use. The bacterial cell pellet was washed twice with phosphatebuffered saline (PBS) before suspension in the same buffer to an optical density (OD) of 0.3 at $600 \mathrm{~nm}$.

\section{Haemolysin assay}

Preparation of red blood cell suspension. A washed suspension of sheep red blood cells $(3 \% \mathrm{v} / \mathrm{v}$ in $0.02 \mathrm{M}$ PBS, pH 7.2) was prepared from sheep blood [21]; $300-\mu 1$ volumes of CCFS or bacterial cell suspension (BCS) were mixed gently with $6 \mathrm{ml}$ of this sheep cell suspension in sterile test tubes, which were incubated at $37^{\circ} \mathrm{C}$ for $3 \mathrm{~h}$ with occasional shaking. The tube contents were then centrifuged at $5000 \mathrm{~g}$ for $15 \mathrm{~min}$. The supernates were collected in separate tubes and used for absorbance determination ( $\mathrm{A}_{545}$ values) against controls. In the control tubes, sterile nutrient broth and PBS were added instead of CCFS and BCS, respectively. Haemolytic activity was expressed as haemoglobin release, $\mathrm{mg} / \mathrm{ml}$ of solution, calculated from the haemoglobin standard absorbance curve.

Congo red binding. The method of Qadir et al. [23] was used. Congo red $(0.003 \% \mathrm{w} / \mathrm{v})$ was incorporated into nutrient agar (NA) before autoclaving. Plates streaked with test strains were incubated at $37^{\circ} \mathrm{C}$ for $18 \mathrm{~h}$. The next day, colonies were examined for the presence (red, $\mathrm{crb}^{+}$) or absence (white, $\mathrm{crb}^{-}$) of Congo red binding.

Congo red uptake assay. S. Typhimurium DT 98 cells were cultured in volumes of $50 \mathrm{ml} / 100 \mathrm{ml}$ flask at $37^{\circ} \mathrm{C}$ for $16-18 \mathrm{~h}$ in various growth media, i.e., brain heart infusion broth (BHI), M-9 glucose medium (M-9) [24], nutrient broth (NB), peptone water (PW), or trypticase soy broth (TSB). The culture was then centrifuged at $10000 \mathrm{~g}$ for $10 \mathrm{~min}$ at $4^{\circ} \mathrm{C}$. The bacterial cell pellet obtained after decanting the CCFS was washed twice with PBS, before suspension in PBS to an OD of 0.3 at $600 \mathrm{~nm}$. The bacterial suspension $(5 \mathrm{ml} /$ tube $)$ was mixed with Congo red $(0.003 \% \mathrm{w} / \mathrm{v})$, kept at $37^{\circ} \mathrm{C}$ for $10 \mathrm{~min}$, then centrifuged at $10000 \mathrm{~g}$ for $10 \mathrm{~min}$ at $4^{\circ} \mathrm{C}$. The supernate was collected in separate tubes to determine its absorbance at $480 \mathrm{~nm}$ against a PBS control. The amount of dye binding to the cells was calculated from the Congo red standard curve as the difference between the amount added to the mixture and the amount remaining in the solution.

\section{Factors affecting haemolysin expression}

Growth medium: Each 100-ml flask, containing $30 \mathrm{ml}$ of growth medium (BHI, M-9, NB, PW or TSB), was inoculated with $100 \mu \mathrm{l}$ of an overnight culture of $S$. Typhimurium DT 98 in NB. Inoculated flasks were kept at $37^{\circ} \mathrm{C}$ for $18 \mathrm{~h}$ and cultures were screened the next day for cell-bound and cell-free haemolysin activity.

Effect of Congo red. The plates were taken out after $4 \mathrm{~h}$ to overlay a thin layer of nutrient agar, while the $S$. Typhimurium DT 98 was cultured on blood agar containing Congo red $(0.001-0.005 \% \mathrm{w} / \mathrm{v})$ at $37^{\circ} \mathrm{C}$. The plates were examined visually after $48 \mathrm{~h}$ for zones of haemolysis. In another experiment, two 50-ml flasks, containing nutrient broth $20 \mathrm{ml}$ either with or without Congo red $(0.003 \% \mathrm{w} / \mathrm{v})$, were inoculated with $100 \mu \mathrm{l}$ of a 16-18-h culture of $S$. Typhimurium DT 98. These flasks were incubated at $37^{\circ} \mathrm{C}$ for $24 \mathrm{~h}$ and then centrifuged at $13000 \mathrm{~g}$ for $15 \mathrm{~min}$. CCFS was separated and stored in separate tubes as described above, to determine haemolytic activity. The cell deposits were washed twice with PBS $(0.02 \mathrm{M}$, $\mathrm{pH}$ 7.2) before suspension in PBS to an $\mathrm{OD}_{600}$ of 0.3 , for the determination of cell-bound haemolytic activity.

Effect of tea extract. Tata brand blended tea $(20 \mathrm{~g})$ was suspended in $100 \mathrm{ml}$ of PBS $(0.02 \mathrm{M}, \mathrm{pH} 7.2)$ in two 
separate beakers. One beaker was kept at room temperature for $3 \mathrm{~h}$ while the contents of the other beaker were boiled for $5 \mathrm{~min}$. Tea infusions were then centrifuged at $6000 \mathrm{~g}$ for $15 \mathrm{~min}$ in separate tubes. Supernates thus obtained were collected in sterile tubes and added as supplements to NA agar $(3-25 \% \mathrm{v} / \mathrm{v})$ before autoclaving. NA containing tea extract was used for making blood agar plates. These plates were used to determine haemolytic activity as described above.

Effect of tea extract on Congo red binding. S. Typhimurium DT 98 was cultured for $18 \mathrm{~h}$ at $37^{\circ} \mathrm{C}$ in various growth media (BHI, NB or TSB). The cultures were then centrifuged and cell deposits were washed in PBS. The bacterial cell density was adjusted to an $\mathrm{OD}_{600}$ of 0.3 . Bacterial cell preparations were mixed with boiled tea extract $(1.5-25 \% \mathrm{v} / \mathrm{v})$ in separate tubes, which were kept at $37^{\circ} \mathrm{C}$ for $10 \mathrm{~min}$. The tubes were then centrifuged at $13000 \mathrm{~g}$ for $15 \mathrm{~min}$ and the supernate was decanted. Bacterial cell deposits were suspended in PBS. These were divided into two equal portions. The test portion was mixed with Congo red $(0.003 \% \mathrm{w} / \mathrm{v})$ and incubated at $37^{\circ} \mathrm{C}$ for $10 \mathrm{~min}$, together with a control (no Congo red), and then centrifuged. The supernates obtained from each tube were collected into separate tubes and scored for absorbance at $400 \mathrm{~nm}$ against PBS. Congo red bound to bacterial cells was calculated as follows: bound Congo red $=\mathrm{A}_{480}$ control supernate with $0.003 \%$ Congo red $-\mathrm{A}_{480}$ test supernate. The amount in $\mu \mathrm{g}$ was determined from the Congo red standard absorbance curve.

Effect of tea extract on bacterial cell viability. A bacterial cell suspension in PBS adjusted to an $\mathrm{OD}_{600}$ of 0.3 and tea extract $(3-25 \% \mathrm{v} / \mathrm{v})$ were mixed in equal proportions in different tubes and incubated at $37^{\circ} \mathrm{C}$. Samples were withdrawn after incubation for $0,3,6,9$ and $24 \mathrm{~h}$, diluted in sterile blanks and spread-plated on to NA. The plates were incubated at $37^{\circ} \mathrm{C}$ for the determination of viable counts. Controls were processed similarly except that an equivalent amount of PBS was added instead of tea extract.

Effect of tea extract on bacterial growth. Sterile NB $(75 \mathrm{ml})$ was mixed with tea extract $(25 \mathrm{ml}$ of $25 \% \mathrm{w} / \mathrm{v}$ infusion in PBS) or PBS (control) in 250-ml flasks, which were then inoculated with $100 \mu \mathrm{l}$ of a $16-18$-h culture of $S$. Typhimurium DT $98\left(\mathrm{OD}_{600}\right.$ of 0.3$)$. Inoculated flasks were incubated at $37^{\circ} \mathrm{C}$ on a rotary shaker $(180 \mathrm{rpm})$. Samples $(100 \mu \mathrm{l})$ were withdrawn after incubation for $0,3,6,9,12$ and $24 \mathrm{~h}$. Each sample was suitably diluted in PBS before spread-plating on NA for the determination of viable counts at $37^{\circ} \mathrm{C}$.

Minimal inhibitory and bactericidal concentrations of tea extract. The boiled tea extract $(25 \% \mathrm{w} / \mathrm{v}$ tea infusion in PBS) was diluted two-fold serially in NB broth $(10 \mathrm{ml} /$ tube $)$. The tubes were inoculated with $20 \mu 1$ from overnight cultures of $S$. Typhimurium DT
98 and incubated at $37^{\circ} \mathrm{C}$ for $18 \mathrm{~h}$. Next day, a loopful of culture from each tube was streaked on to an NA plate. The plates were examined for bacterial growth after incubation at $37^{\circ} \mathrm{C}$ for $18 \mathrm{~h}$. The lowest concentration of tea extract that showed no growth was taken as the minimal bactericidal concentration.

\section{Statistical analysis}

Karl Pearson's coefficient of correlation and the unpaired Student's $t$ test were used for the analysis of data.

\section{Results}

Of the 29 strains of salmonellae screened for haemolytic activity, some were found to be very weakly haemolytic and produced a barely visible, narrow zone of haemolysis around the colonies on bilayered blood agar plates at $37^{\circ} \mathrm{C}$. However, these strains produced wider zones of haemolysis when cultured under micro-aerobic conditions. An increase in the size of the zone of haemolysis was also observed if the incubation at $37^{\circ} \mathrm{C}$ was prolonged to 48 or $72 \mathrm{~h}$ [21]. The Congo red binding and haemolysin activity were highest for $S$. Typhimurium DT 98. $S$. Typhimurium DT 98 colonies $(24 \mathrm{~h})$ on Congo red blood agar were small and discrete, with a dark red centre, lighter outer zone and a zone of haemolysis around the colonies (Fig. 1). In contrast, the colonies on layered blood agar $(24 \mathrm{~h})$ were larger, with a narrow zone of haemolysis. The haemolytic zone around the colonies widened on further incubation $(48 \mathrm{~h})$ at $37^{\circ} \mathrm{C}$ (Fig. 1).

\section{Factors affecting haemolysin activity and expression}

The haemolysin expression was minimal in synthetic medium, greatest in BHI and expressed in the other growth media in the order $\mathrm{BHI}>\mathrm{NB}>\mathrm{TSB}>\mathrm{M}-9$. Cell-bound haemolysin correlated with the haemolysin activity in the CCFS $(r=+0.89)$. Any alteration (increase or decrease) in either type of haemolysin had the same effect on the other. The ratio between the cell-bound and cell-free haemolysin activities of strains cultured in different media was also similar (Table 1). However, the results of a comparison of the haemolysin activity of $S$. Typhimurium DT 98 cultured in NB with and without Congo red $(0.003 \% \mathrm{w} / \mathrm{v})$ showed greater haemolysin activity $(\mathrm{p}<0.05)$ in broth supplemented with Congo red (CCFSH; $206 \mathrm{HU}, 1.36 \mathrm{mg}$ haemoglobin released $/ \mathrm{ml}$ ). In contrast, cell-bound haemolysin (CBH) activity was negligible (19 HU, $0.019 \mathrm{mg}$ haemoglobin released $/ \mathrm{ml}$ ) in broth supplemented with Congo red (Table 2). Under similar conditions, the haemolysin activity was found to be $56 \mathrm{HU}$, or $0.041 \mathrm{mg}$ haemoglobin released $/ \mathrm{ml}$, in CCFSH and $135 \mathrm{HU}$, or $0.080 \mathrm{mg}$ haemoglobin released $/ \mathrm{ml}$, for $\mathrm{CBH}$ in NB cultures (control). The addition of Congo red appeared to facilitate the release of haemolysin into 
a

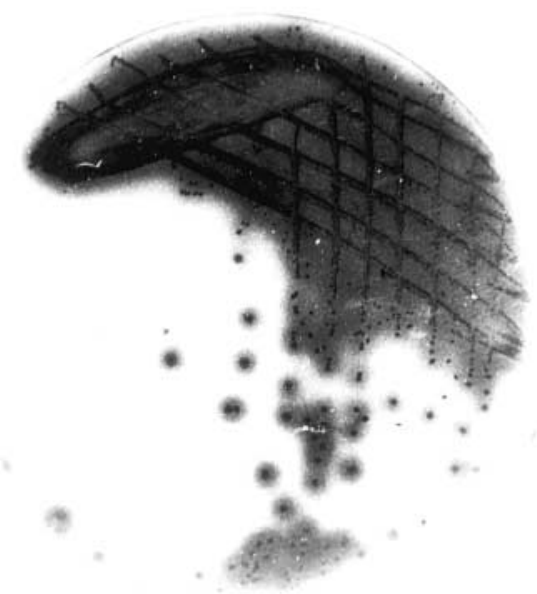

b

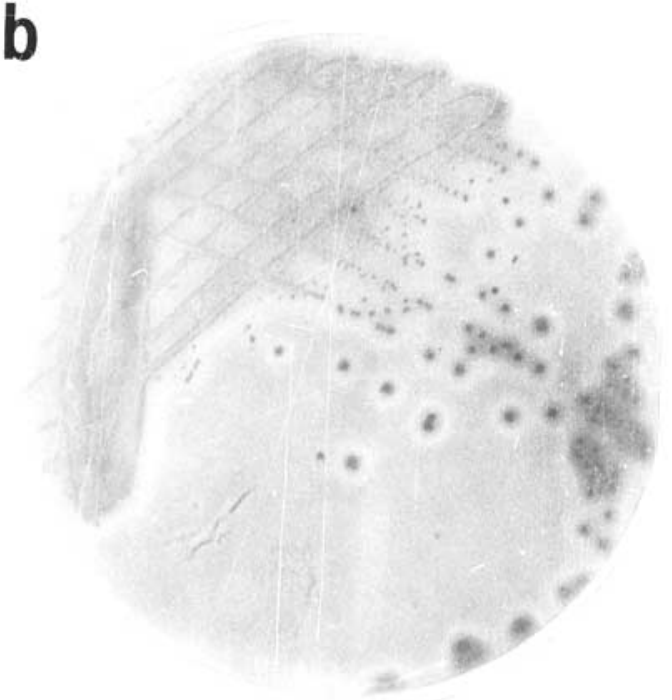

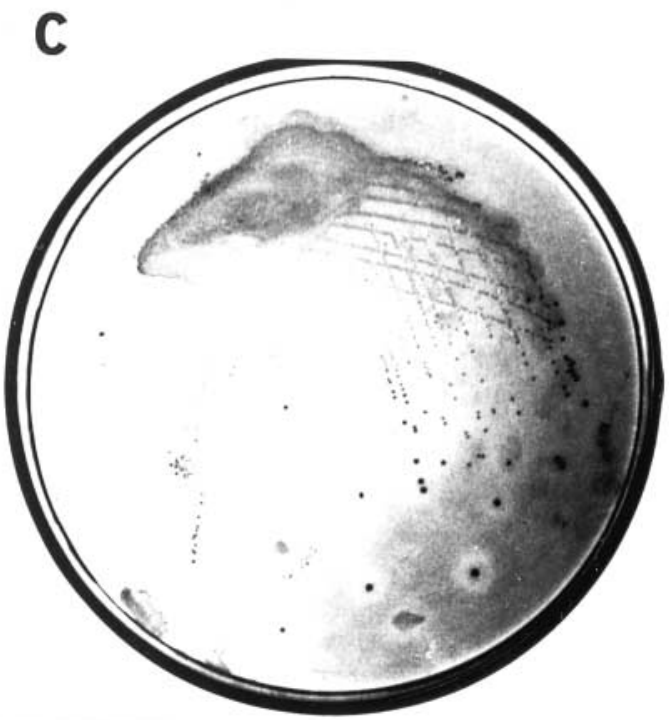

Fig. 1. Haemolytic activity of $S$. Typhimurium DT 98 cultured under micro-aerobic conditions at $37^{\circ} \mathrm{C}$. Colonies appearing on layered blood agar after incubation for $24 \mathrm{~h}$ are larger, with a narrow zone of haemolysis (a). The zone of haemolysis is wider in cultures incubated for $48 \mathrm{~h}(\mathbf{b})$, whereas colonies are smaller and have wider zones of haemolysis after incubation for $24 \mathrm{~h}$ on blood agar supplemented with Congo red, $0.003 \% \mathrm{w} / \mathrm{v}(\mathbf{c})$.

Table 1. Effect of growth medium on cell-bound and cell-free haemolysin production by $S$. Typhimurium DT 98 cultured in different growth media

\begin{tabular}{lccccc}
\hline & \multicolumn{4}{c}{ Haemolysin activity } \\
\cline { 2 - 3 } & \multicolumn{2}{c}{ Haemoglobin released $(\mathrm{mg} / \mathrm{ml})$} & \multicolumn{3}{c}{$\mathrm{A}_{545}$} \\
\cline { 2 - 3 } \cline { 5 - 6 } Growth medium & CBH & CCFSH & & CBH & CCFSH \\
\hline M-9 glucose & 0.019 & 0.000 & & 0.020 & 0.000 \\
NB & 0.060 & 0.020 & & 0.088 & 0.019 \\
TSB & 0.057 & 0.019 & & 0.086 & 0.021 \\
BHI & 0.080 & 0.049 & & 0.138 & 0.068 \\
\hline
\end{tabular}

$\mathrm{CBH}$, bacterial cell density adjusted to $\mathrm{OD}_{600} 0.3$; $\mathrm{CCFSH}$, culture-cell-free supernate activity; $\mathrm{NB}$, nutrient broth; BHI, brain-heart infusion broth; TSB, trypticase soy broth; CBH versus CCFSH, $\mathrm{p}<0.05, r=+0.89$.

the growth medium. The haemolysin that should have adsorbed on to the bacterial surface was also excreted. The expression of wider haemolytic zones by strains cultured on Congo red blood agar further confirms the above observation, whereby varying zones of haemo- lysis were observed on blood agar containing different concentrations of Congo red $(0.001-0.005 \% \mathrm{w} / \mathrm{v})$.

The addition of tea extract to the growth medium at higher concentrations $(\geqslant 6 \%)$ inhibited haemolysin 
Table 2. Effect of Congo red supplementation $(0.003 \%)$ to NB on haemolysin expression by $S$. Typhimurium DT 98 cultured at $37^{\circ} \mathrm{C}$ for $24 \mathrm{~h}$

\begin{tabular}{|c|c|c|c|c|}
\hline \multirow[b]{3}{*}{ Growth medium } & \multicolumn{4}{|c|}{ Mean (SD) haemolysin activity } \\
\hline & \multicolumn{2}{|c|}{ Haemoglobin released $(\mathrm{mg} / \mathrm{ml})$} & \multicolumn{2}{|c|}{$\mathrm{A}_{545}$} \\
\hline & $\mathrm{CBH}$ & CCFSH & $\mathrm{CBH}$ & CCFSH \\
\hline NB with Congo red & $0.019(0.006)$ & $1.360(0.48)$ & $0.019(0.007)$ & $0.026(0.018)$ \\
\hline NB & $0.080(0.015)$ & $0.041(0.023)$ & $0.135(0.074)$ & $0.056(0.024)$ \\
\hline
\end{tabular}

production, whereas at lower concentrations $(1.5-3 \%)$, haemolysin production was stimulated and the strains produced wider zones of haemolysis on blood agar supplemented with tea extract. Similarly, the differences in Congo red binding were also seen in bacterial cell suspensions cultured in different growth media that contained tea extract or differed in nutritional content. The degree of Congo red binding in different cultures corresponded to their haemolysin activities in the order BHI $>$ NB $>$ M-9 glucose medium. The Congo red binding was always higher for bacterial cells cultured in medium supplemented with tea extract than for those cultured in the same medium without tea extract. Characteristically, the Congo red binding was also highest in bacterial cells cultured in the presence of lower concentrations of tea extract (Table 3) ( $r=-0.89$ in NB, -0.93 in TSB and -0.51 in BHI). Congo red binding and haemolysin activity in $S$. Typhimurium DT 98 appeared to be a directly correlated phenomenon $(r=+0.998$ in $\mathrm{NB},+0.69$ in TSB and +1.0 in $\mathrm{BHI})$.

A successive decrease in bacterial viable count was observed as the exposure time of $S$. Typhimurium DT 98 to tea extract $25 \% \mathrm{v} / \mathrm{v}$ in PBS or NB increased. The decrease in viable count was slower in bacterial cells suspended in NB (Table 4). The viable count was $<1$ for bacterial cells suspended in PBS containing tea extract, whereas it was still $2 \times 10^{3} \mathrm{cfu} / \mathrm{ml}$ after $9 \mathrm{~h}$ in NB containing tea extract and became $<1$ only after $24 \mathrm{~h}$. Boiled tea extract at $25 \% \mathrm{v} / \mathrm{v}$ was found to be bactericidal for $S$. Typhimurium DT 98 .

\section{Discussion}

The pathogenic salmonellae often have a long passage within the host before they induce a symptomatic infection. Strains effectively compete with host defences at each phase, expressing phase-specific factors and inducing cell-surface changes $[4,15]$. Entry through the intestine followed by transient bacteraemia leads to the establishment of foci of infection in the liver and spleen. In the present study, haemolysin, an important virulence factor $[25,26]$ that is expressed optimally in $S$. Typhimurium DT 98 under microaerobic conditions such as those found in its intestinal phase, was examined. Haemolysin could be useful in epithelial cell invasion, the induction of cell-surface factors, survival in macrophages and the counteraction of host immune defences, particularly those nonspecific defences encountered in the initial phases of infection $[21,27]$. The direct correlation between the Congo red binding and haemolysin activity of $S$. Typhimurium DT 98 under conditions that favour haemolysin production is indicative of associated phenotypic changes in strains cultured under different conditions. Similar changes have been reported in strains of Pseudomonas aeruginosa cultured from the sputum of patients with cystic fibrosis, and in those cultured in iron-deficient conditions in vitro [28]. $S$ Typhimurium DT 98 cells cultured either in medium containing Congo red $(0.003 \% \mathrm{w} / \mathrm{v})$ or exposed to Congo red before haemolysin assay expressed very little cell-bound haemolysin activity. On the other hand, the haemolytic activity of CCFS from strains cultured in growth media containing Congo red was much higher than that shown by the same strain after culture in the absence of Congo red.

These results appear to show that: (1) some of the haemolysin adsorbs to the bacterial cell surface, and (2) the loci for binding Congo red and adsorbing haemolysin are either very similar or identical, as Congo red binding to bacterial cells resulted in the complete loss of the cell-bound haemolysin activity of the strain.

It is interesting that the Congo red binding appeared to activate rather than inhibit haemolysin synthesis or secretion, as the haemolysin activity of CCFS from cultures grown in the presence of Congo red was much higher than that from cultures grown in medium without Congo red. During synthesis and secretion of haemolysin, some of the haemolysis adsorbs to the bacterial cell surface. Congo red present in the medium seems to bind to these adsorption sites as well. Hence the amount of haemolysin synthesised continuously is excreted and, in addition, the haemolysin bound to receptors on the bacterial cell surface is also secreted [29] resulting in greater haemolysin activity in the CCFS. On Congo red agar, the haemolytic strains produced smaller colonies but with wider zones of haemolysis. 
Table 4. Death rate kinetics of $S$. Typhimurium DT 98 cells suspended in NB and PBS (0.02 M, pH 7.2) with tea extract $(25 \% \mathrm{v} / \mathrm{v}$ of $25 \% \mathrm{w} / \mathrm{v}$ boiled tea extract in PBS)

\begin{tabular}{lccr}
\hline $\begin{array}{l}\text { Exposure } \\
\text { time } \\
\text { (h) }\end{array}$ & \multicolumn{3}{c}{ Bacterial viable count $(\mathrm{cfu} / \mathrm{ml})$ in } \\
\cline { 2 - 4 } & PBS + tea & NB + tea & NB control ${ }^{*}$ \\
\hline 0 & $2.9 \times 10^{5}$ & $2.6 \times 10^{5}$ & $3.0 \times 10^{5}$ \\
3 & $5.0 \times 10^{4}$ & $9.0 \times 10^{4}$ & $5 \times 10^{7}$ \\
6 & 30 & $2.0 \times 10^{4}$ & $7.6 \times 10^{9}$ \\
9 & 0 & $3.0 \times 10^{3}$ & $5 \times 10^{9}$ \\
24 & 0 & 0 & $8 \times 10^{9}$ \\
\hline${ }^{*} S$. Typhimurium DT 98 cells in NB without tea extract.
\end{tabular}

The effect of the addition of tea extract to blood agar on haemolysin production was inhibitory at concentrations of $\geqslant 6 \% \mathrm{v} / \mathrm{v}$, but stimulatory at lower concentrations $(1.5-3 \% \mathrm{v} / \mathrm{v})$. These findings corroborate the earlier report of antihaemolysin activity of tea and coffee extracts against Staphylococcus aureus and Vibrio parahaemolyticus haemolysins [30]. To investigate the dual effect of boiled tea extract on haemolysin production, tea extract was evaluated for its antibacterial activity against $S$. Typhimurium DT 98 . At the higher concentration of $25 \% \mathrm{v} / \mathrm{v}$, the tea extract was found to be bactericidal for $S$. Typhimurium DT 98 . The strain showed no haemolytic activity when cultured on blood agar plates supplemented with tea extract at concentrations of $6 \%$ or $12 \% \mathrm{v} / \mathrm{v}$, and the colonies produced were smaller. The haemolysin expression was also greater in strains cultured under micro-aerobic conditions in growth medium containing low concentrations of tea extract. This stimulation of haemolytic activity may be related to altered hydrophobicity or an alteration in bacterial cell surface characteristics like the changes induced by Congo red binding. It is surprising that even the Congo red binding by $S$. Typhimurium DT 98 cells pre-treated with tea extract at a concentration of $6 \%$ or $12 \% \mathrm{v} / \mathrm{v}$ was negligible when compared with the Congo red bound to bacterial cells exposed to tea extract at concentrations of $1.5-3 \% \mathrm{v} / \mathrm{v}$. Pre-treatment with low concentrations of tea extract appeared to up-regulate the receptors for Congo red binding and haemolysin adsorption/secretion, whereas higher concentrations probably masked such receptors completely. These activities have also been correlated with the adhesiveness of clinical isolates of shigellae to colonic epithelial cells $[23,31]$. The results of the present study appear to confirm a direct correlation between Congo red binding and haemolysin expression by $S$. Typhimurium DT 98.

\section{References}

1. Foster JW, Spector MP. How Salmonella survive against the odds. Annu Rev Microbiol 1995; 49:145-174.

2. Barrow PA, Huggins MB, Lovell MA. Host specificity of Salmonella infections in chickens and mice is expressed in 
vivo primarily at the level of reticuloendothelial system. Infect Immun 1994; 62: 4602-4610.

3. Miller SI, Hohmann EL, Pegues DA. Salmonella (including Salmonella typhi). In: Mandell GL, Bennett JE, Dolin R (eds) Principles and practice of infectious diseases, 4th edn, vol 2. New York, Churchill Livingstone. 1995: 2013-2037.

4. Lee IS, Slonczewski JL, Foster JW. A low pH inducible, stationary-phase acid tolerance response in Salmonella typhimurium. J Bacteriol 1994; 176: 1422-1426.

5. Libby SJ, Goebel W, Ludwig A et al. A cytolysin encoded by Salmonella is required for survival within macrophages. Proc Natl Acad Sci USA 1994; 91: 489-493.

6. Ludwig A, Tengel C, Bauer S et al. SlyA, a regulatory protein from Salmonella typhimurium induces a haemolytic and poreforming protein in Escherichia coli. Mol Gen Genet 1995; 49: 474-486.

7. Foster JW, Park YK, Bang IS et al. Regulatory circuits involved with $\mathrm{pH}$-regulated gene expression in Salmonella typhimurium. Microbiology 1994; 140: 341-352.

8. Haque MA, Yoshino S, Ohki K, Inada S, Kohashi O. Effect of growth condition on in-vivo susceptibility of Shigella dysenteriae type 1 to killing by murine peritoneal macrophages. $J$ Med Microbiol 1996; 44: 99-104.

9. Qadir F, Haque MA, Hossain A, Azim T, Alam K, Albert MJ. Role of Shigella dysenteriae type 1 slime polysaccharide in resistance to serum killing and phagocytosis. Microb Pathog 1993; 14: 441-449.

10. Bondarenko VM, Golubev AV, Koriagina IP. [Influence of hemolytic plasmids on the development of the "killing" effect in various species of enterobacteria.] Zh Mikrobiol Epidemiol Immunobiol 1983; (9): 50-53.

11. Hromockyj AE, Tucker SC, Maurelli AT. Temperature regulation of Shigella virulence, identification of repressor gene virR, an analogue of hns, and partial complementation by tyrosyl transfer RNA (tRNA, Tyr). Mol Microbiol 1992; 6: 2113-2124

12. Pepe JC, Badger JL, Miller VL. Growth phase and low $\mathrm{pH}$ affect the thermal regulation of Yersinia enterocolitica inv gene. Mol Microbiol 1994; 11: 123-135.

13. Sankaran K, Ramachandran V, Subranhmanyan YVBK, Rajarathnam S, Elango S, Roy RK. Congo red-mediated regulation of levels of Shigella flexneri 2a membrane proteins. Infect Immun 1989; 57: 2364-2371.

14. Ishiguro EE, Ainsworth T, Trust TJ, Kay WW. Congo red agar, a differential medium for Aeromonas salmonicida, detects the presence of the cell surface protein array involved in virulence. J Bacteriol 1985; 164: 1233-1237.

15. Buchmeirer N, Bossie S, Chen C-Y, Fang FC, Guiney DG, Libby SJ. SlyA, a transcriptional regulator of Salmonella typhimurium, is required for resistance to oxidative stress and is expressed in the intracellular environment of macrophages. Infect Immun 1997; 65: 3725-3730.

16. Jones BD, Ghori N, Falkow S. Salmonella typhimurium initiates murine infection by penetrating and destroying the specialized epithelial M cells of the Peyer's patches. J Exp Med 1994; 180: 15-23.

17. Daniels JJD, Autenrieth IB, Ludwig A, Goebel W. The gene slyA of Salmonella typhimurium is required for destruction of $M$ cells and intracellular survival but not for invasion or colonization of murine small intestine. Infect Immun 1996; 64 5075-5084.

18. Toda M, Okubo S, Hiyoshi R, Shinamura T. The bactericidal activity of tea and coffee. Lett Appl Microbiol 1989; 8 $123-125$.

19. Sakanaka S, Kim M, Taniguchi M, Yamamato T. Antibacterial substances in Japanese green tea extract against Streptococcus mutans, a cariogenic bacterium. Agric Biol Chem 1989; 53: 2307-2311.

20. Diker KS, Akan M, Hascelik G, Yurdakök M. The bactericidal activity of tea against Campylobacter jejuni and Campylobacter coli. Lett Appl Microbiol 1991; 12: 34-35.

21. Uppal MK, Rishi P, Tiwari RP. Factors affecting hemolysin expression and its associated characteristics in Salmonella typhimurium and S. typhi. Ind J Med Microbiol 1998; 16: $169-174$.

22. Lapage SP, Shelton JE, Mitchell TG. Media for the maintenance and preservation of bacteria. In: Norris JR, Ribbons DW (eds) Methods in microbiology, vol 3A. London, Academic Press. 1970: 1-133.

23. Qadir F, Hossain SA, Ciznár I et al. Congo red binding and salt aggregation as indicators of virulence in Shigella species. J Clin Microbiol 1988; 26: 1343-1348.

24. Atlas RM, Parks LC (eds). Handbook of microbiological media. Boca Raton, CRC Press. 1993: 529.

25. Siegfried L, Puzová $\mathrm{H}$, Kmetová $\mathrm{H}$, Keresteöová A. Killing of haemolytic and non-haemolytic Escherichia coli strains in human serum and polymorphonuclear leucocytes. $J$ Med Microbiol 1992; 37: 3-7.

26. Daskaleros PA, Stoebner JA, Payne SM. Iron uptake in Plesiomonas shigelloides: cloning of the genes for the hemeiron uptake system. Infect Immun 1991; 59: 2706-2711.

27. König W, Faltin Y, Scheffer J, Schöffer, Braun V. Role of cellbound hemolysin as a pathogenicity factor for Serratia infections. Infect Immun 1987; 55: 2554-2561.

28. Brown MRW, Anwar H, Lambert PA. Evidence that mucoid Pseudomonas aeruginosa in the cystic fibrosis lung grows under iron restricted conditions. FEMS Microbiol Lett 1984, 21: $113-117$.

29. Grenier D. Hemin-binding property of Porphyromonas gingivalis outer membrane. FEMS Microbiol Lett 1991; 77: 45-49.

30. Okubo S, Ikigai $H$, Toda $M$, Shimamura $T$. The antihaemolysin activity of tea and coffee. Lett Appl Microbiol 1989; 9: 65-66.

31. Kavita S. Shigella flexneri hemolysins: role in pathogenesis and immunoprophylactic activities. MSc thesis, Panjab University, Chandigarh, India, 1995. 